\title{
PROPOSALS FOR REHABILITATION EMPLOYMENT IN FORESTRY IN BRITISH COLUMBIA
}

\author{
BY C. D. ORChaRd \\ Chief Forester, Victoria, B.C.
}

$\mathrm{B}^{\mathrm{r}}$ RITISH Columbia is endeavouring today to administer and protect more than 115,000 square miles of productive forest land on which we depend for more than 40 per cent of our total income. To do this we had, in 1939, 44 Foresters and Inspectors and 59 Rangers. Our Ranger Districts averaged about 1,950 square miles. Had these been arranged in squares, checker-board fashion, each Ranger's square would have measured a little more than 44 miles on a side. Actually this mileage of productive land each Ranger must cover is scattered through an area more than twice as big. Obviously the areas are too great for any one man to cover and the present staff could be doubled before current routine could be adequately handled.

Present developments in the north-the Alaska road, the Prince GeorgeAlaska railway, and expanding air facilities-are rapidly opening up another great area for which forest administration and protection is still to be pro. vided.

In the meantime, with changing conditions and progressive depletion of mature forest stands, a multitude of problems call for investigation and solution. Particularly in the field of forest protection, modern developments in equipment, organization and technique offer, as never before, the possibility of fully effective measures, were adequate staff and equipment available. Within the past few years, in the U.S. National Forests of the Pacific Northwest States, acres burned per year per thousand acres of forest land have been reduced from more than 80 to about 16 . The same results can readily be attained in British Columbia, were men and equipment available.

Forest administration offers one of the best avenues for rehabilitation in work of immediate and lasting value, both in permanent and seasonal employment.

The minimum numbers of additional men that could be absorbed in these services are estimated to be:

Permanent

Technical Foresters ................... 25

Mechanical Engineers ..................... 2

Supervisors and Inspectors $\ldots \ldots \ldots \ldots \ldots \ldots \ldots$;

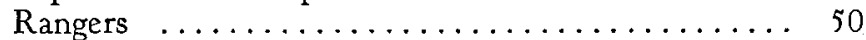

Miscellaneous Office Staff ................... 25

Miscellaneous Technical and Skilled ........... 25

Labour ........................... 500

Seasonal

Assistant Rangers, Patrol, etc. ............... 505

"Stand-by" fire and improvement crews .......... 600 


\section{REFORESTATION}

\section{Technical Factors}

In a program of reforestation an opportunity is provided to employ large numbers of men during the period when planting operations in the field are in full swing. However, it has been found in British Columbia that it is advisable to plant only in the spring and this means that activities are mainly confined to the months of March and April. Employment is at a peak during that period and as soon as the planting has been completed it is necessary to reduce crews by approximately 90 per cent, the remaining 10 per cent being sufficient to prepare planting sites and grow the young trees for the following year's operations. In brief, any program of reforestation is seasonal in its labour demands and must be co-ordinated with some other program if full employment is to be provided for the necessary personnel.

No new legislation would be necessary in an extension of the present program and the Forest Branch personnel could be expanded to provide the necessary supervision.

\section{Present Program}

The first Forest Branch efforts in reforestation resulted in the establishment in 1927 of an experimental nursery on Shelbourne Street, Victoria. The purpose was to develop nursery techniques in advance of the time when a permanent forest nursery would be established. In the winter of 1929-30 clearing was started at the Green Timbers area on the Cariboo Highway, five miles south of New Westminster. The first plantations were set out in 1931 and from then until the end of 1938 a total of only 1,358 acres were planted.

This was all experimental and it served its purpose well. When it was decided to embark on a planting program, the Green Timbers Nursery was producing two-year-old trees at a cost of about $1 / 4 \phi$ each and the total cost of planting had been reduced to a figure where planting was a practical business undertaking.

On August 9, 1938, the Honourable the Minister of Lands announced that as soon as the necessary facilities could be established it would be the policy of the Department to plant up to 10,000 acres of cut-over land per year on Vancouver Island and the adjacent Mainland. Facilities were extended at Green Timbers until 22 acres are now in nursery with an annual production of $6,000,000$ trees. The new program also called for the establishment of another nursery and the new one was started about one mile west of the village of Campbellton, Vancouver Island. Its annual capacity was to be $4,000,000$ trees, thus giving a total of $10,000,000$ trees for planting each year.

In the last two years the total acreage planted has increased rapidly so that as of this date 22,495 acres have been restocked and at the present rate of progress nearly 10,000 acres will be added each year. Two new nursery sites have been selected on instructions to double the present program as soon as labour conditions will permit. 


\section{Possible Extension of Program}

By establishing new industries it would be practical to double or even triple the present program. However, it would take a year or two to develop the new land and then two years to grow the planting stock so unless some pre-organization were under way there would be a time lag of three years at least before the increased production would be available from the nurseries.

The planting sites are available in that there is an estimated $1,000,000$ acres of forest land on the Lower Coast that are not reproducing satisfactorily.

\section{Employment Afforded}

For each unit of 10 million trees to be planted annually the following man-power is needed:

1. 12 men full time in the nurseries;

2. 50 men full time preparing planting sites;

3. 550 men for 2 to $2 \frac{1}{2}$ months for planting and extra work at the nurseries during March and April.

The above requirements would be in effect as long as the program lasted.

\section{Costs}

Average annual cost for each unit of $10,000,000$ trees would be $\$ 150,000$.

This is a valuable, practical, and very necessary project if forest production is to be maintained at a reasonably high level in British Columbia.

FARM WOODLOTS

\section{Review of Present Situation}

Up to the present the readily accessible mature forests have yielded ample supplies of material for the forest industries and our domestic requirements. However, as logging operations become farther and farther removed from the cities and more densely settled farming communities the value of small areas of forest close at hand increase. On most farms of any size there is some land which is too poor to justify intensive cultivation and in the older countries of the world such areas are devoted to growing trees. From the farm woodlot comes the fuelwood, the fence posts, the lumber for new build. ings or repairing old ones, not to mention the products such as logs or pulp: wood which may be sold and thereby become the source of a supplementary income.

In British Columbia the farm woodlot is slowly taking shape and there are signs of development in the Lower Fraser Valley. It is believed that the best way to encourage this development will be by demonstration and education. With this in mind the Forest Branch is already sponsoring a system of demonstration woodlots. Thirty-one areas are already selected and about to be reserved for that purpose in the Fraser Valley and on Vancouver Island.

\section{Rehabilitation Aspects}

As a rehabilitation project these woodlots could be used to supply profitable employment for about 500 men who would live at home and be transported to work each day, thereby eliminating any camps. The work would 
comprise thinning, pruning, improvement cutting, snag felling and some planting.

The staff of the Forest Branch could be expanded providing additional employment for technical men to give the necessary supervision and it would cost about $\$ 1.50$ per man-day exclusive of any wages paid. The project could very well run for two years employing 500 men at a cost of $\$ 225,000$. per year. Part-time employment, so valuable in farming communities, would be provided for a considerable number of men for maintenance and harvest on a permanent basis. This permanent employment should be self-liquidating in the sale of the product.

There is no way of estimating the general permanent employment this project. would develop. Woodlots are adapted almost exclusively to the farming community. The project is a practical one and unquestionably valuable from a long term standpoint.

\section{Parks ANd Recreation}

\section{Review of Present Situation}

For years past, the forests have constituted the major economic background on which British Columbia has developed. During this long period our emphasis has been placed almost exclusively on logs and lumber but in more recent years we have begun to realize that, important as these primary products may be, there are other profits to be derived from our forest areas which in the aggregate may be of equal value. Amongst these secondary but highly valuable uses are watershed protection, control of erosion, protection of game and fish, aesthetic values which invite the tourist, and recreation. The tourist trade and recreation particularly have come to the fore with possibilities in business, revenue and public health probably quite beyond our present day imagination.

The "Parks Act" which is incorporated in the "Forest Act" provides for the establishment of parks from time to time at the discretion of the Government and the classification of new parks under three classes, A, B, and $C$. Class $A$ parks will be reserved exclusively for recreational purposes and no timber will be disposed of in parks of this class except in minor quantities for the express purpose of park improvement. Class B parks will be under a modified form of control for the primary object of recreation but will permit other occupation and use at the discretion of the Minister. Class $\mathrm{C}$ parks are primarily of local interest and are placed under the administration of a local Board appointed by the Minister.

A park system should include all types of recreational use and in this respect British Columbia is particularly fortunate. The present parks include outstanding scenic values-- some near the main toutes of travel, others, primitive areas-each affording the recreationist a wide variety of interest. The proper management of parks assures a perpetual playground for the big game hunter, the fisherman, the wild life and nature enthusiast. Provision of facilities for the skier is not overlooked. Nature lovers, sportsmen and conservationists alike can all indulge in their favourite pastime. 
At present, British Columbia has 49 parks with a total acreage of over 9,000,000 acres. Included are such well known ones as Strathcona, Garibaldi, Mt. Robson, Tweedsmuir, Wells Gray, Elk Falls, Little Qualicum Falls, Englishman's River Falls, and Mount Seymour. These areas, dedicated to the enjoyment of our citizens and visitors, are not rivalled elsewhere in the Dominion, either for natural attractiveness or in extent, as shown by the following tabulation of park areas for Canada.

\begin{tabular}{|c|c|c|c|}
\hline Province & $\begin{array}{l}\text { National } \\
\text { Parks } \\
\text { Sq. Miles }\end{array}$ & $\begin{array}{l}\text { Provincial } \\
\text { Parks } \\
\text { Sq. Miles }\end{array}$ & $\begin{array}{c}\text { Total } \\
\text { Sq. Miles }\end{array}$ \\
\hline Prince Edward Island & 7.00 & $\ldots .$. & 7.00 \\
\hline Nova Scotia & 390.60 & & 390.60 \\
\hline New Brunswick & .09 & & .09 \\
\hline Quebec ...... & .33 & $5,255.00$ & $5,255.33$ \\
\hline Ontario & 11.72 & $4,298.15$ & $4,309.87$ \\
\hline Manitoba & $1,148.12$ & & $1,148.12$ \\
\hline Saskatchewan & $1,869.00$ & $1,146.38(\mathrm{a})$ & $3,015.38$ \\
\hline Alberta & $20,937.20$ & 2.27 & $20,939.47$ \\
\hline British Columbia & $1,715.00$ & $14,075.68$ & $15,790.68$ \\
\hline Northwest Territories & $3,625.00$ & $\ldots \ldots$ & $3,625.00$ \\
\hline Total & $29,704.06$ & $24,777.48(\mathrm{a})$ & $4,481.54$ \\
\hline
\end{tabular}

(a) In addition, 537.21 sq. miles of provincial forest reserves in Saskatchewan are administered under provincial park regulations.

Certain development work has already been undertaken in Provincial Parks by the Forest Service and two Rangers now devote their full energies to park activities. In addition, there are attendants on duty during the summer months at five developed scenic spots on Vancouver Island.

Detailed plans have been drawn up to cover the development of seven of the more important areas and, as time and staff permit, these plans will be extended to additional parks.

The park situation, therefore, is already adequately provided for so far as the basic set-up is concerned. We have over $9,000,000$ acres in 49 carefully selected parks distributed province-wide. Several other proposed park areas are awaiting examination. We can create parks at will under existing legislation in various types of reserves. We have an experienced technical engineer and administrative staff that can readily be expanded.

\section{Co-ordination With Reforestation}

The program of park development could very well be co-ordinated with the reforestation program so that the 550 men needed for planting in the spring would be employed full time. Present information indicates that this number of men would be the most practical size of crew for planting operations for the next two or three years. However, if it were a matter of necessity, there is no question but that an additional 500 men could be put to work for two years. 


\section{Rehabilitation}

The parks project as a whole, we believe, is admirably adapted to rehabilitation and is very closely allied to the tourist industry. There is a very definite need for the development of park areas. The work would be healthful, constructive, and should appeal to any man inclined to outdoor work. It offers almost unlimited scope for employment of foresters, engineers, park attendants, administrators and labour. It will provide a large number of permanent jobs for maintenance and administration after im. provements have been made. It will be in large measure self-liquidating through increased tourist and holiday traffic, even though an exact accounting in this regard cannot be compiled.

It is especially attractive in that much detailed planning has already been done and the lack of detailed plans, and the impossibility of making plans until qualified men are available after the war is going to be one of the chief handicaps in inaugurating many other types of useful projects on short notice.

\section{Cost}

An average of $\$ 2.00$ per day per man, exclusive of wages, would adequately finance a comprehensive parks project. In other words, a 500-man project would cost (for board, housing, equipment, material and supervision) $\$ 1,000$. per day; or, on the basis of 300 days per year, $\$ 300,000$. annually.

A minimum of 500 men could readily be employed on park development works. In some cases in the Interior, employment would have to be seasonal but, by correlating with other projects, at least this number could be employed throughout the year.

EDITOR'S NOTE: At the opening of the afternoon session on Monday, January 24, it was decided that, rather than discuss each report as it was submitted, discussion should be deferred until the reports of the Dominion and all Provincial Forest Authorities had been read. The material which follows falls into two classes: (1) comments at the time reports were read by the individuals submitting same, to supplement them, and (2) subsequent discussion from the floor. The former appear in italics to distinguish them from the latter.

In justice to the commentators it should be pointed out that this material is reproduced from the transcript of proceedings, unchanged except for some slight editing by the undersigned. It has not been feasible to refer the text to the individual commentators for editing and approval before printing.

Eric Druce. 